Forum: Global Prague: Renaissance and Reformation Crossroads 


\title{
Global Prague: Renaissance and Reformation Crossroads
}

\author{
Introduction: Golden Prague-Beyond Rudolf
}

\author{
Howard Louthan
}

Department of History, University of Minnesota, Minneapolis and St. Paul, Minnesota, USA

Corresponding author: Howard Louthan, email: hlouthan@umn.edu

Reading these articles in our AHY Forum brought back a flood of memories to my last days as a university undergraduate at Emory University when I first encountered Emperor Rudolf II and Renaissance Prague in a course taught by the late James Allen Vann. What captivates us about the past? What prompts naive undergraduates to take that fateful step and pursue a $\mathrm{PhD}$ in history? For me, it was simply Rudolf. I was not alone. The quizzical emperor ensconced in his castle high above the city has intrigued the imaginations of many. There is certainly irony in this, for Rudolf as an emperor was no success. He ended his reign an ineffective ruler browbeaten by his own brother to abdicate as king of Bohemia. But if he failed politically, there were lasting triumphs elsewhere. Rudolf s contemporary, the Flemish painter and theoretician Karel van Mander, famously pointed to Prague and the emperor as the "greatest art patron in the world." And what emperor can boast that his most acclaimed "likeness" was a collage of fruits and vegetables, a portrait executed by a student of Leonardo da Vinci?

The emperor's allure has lasted long beyond his death. Rudolfine myths inspired Karel Čapek in the Makropulos Affair to explore themes of immortality based on a mysterious alchemical recipe discovered by one of the emperor's physicians, a story that later inspired Leoš Janáček to write his great opera. Leo Perutz, a contemporary of Kafka who shared with him a passion for the strange and fantastic, recreated Rudolfine Prague in one of his novels and told of a magical love affair between the emperor and a secretive woman of the Jewish ghetto. The Nobel laureate, José Saramago, wrote an entire novel about a famous elephant connected to the court of Rudolfs father, Maximilian II. And then there is the Golem, one of the great monsters of Central Europe. From the novels of Gustav Meyrink and I. B. Singer to the marvelous silent films of Paul Wegener, the tales of this monster created by the Maharal, the chief rabbi of Prague, to save the ghetto has become a staple of the horror genre. When one tires of legend, there are stories of true crime, most notedly the grisly activities of the emperor's illegitimate son Don Julio Caesar. The sadistic prince, whom Rudolf dispatched to the picturesque castle at Český Krumlov, took up with the daughter of the local barber. Violent and abusive, Don Julio regularly beat and cut her before throwing her from a window of the castle. She miraculously survived the fall only to be dragged back to her prison, where the disturbed prince finally murdered and then dismembered her.

My entry to the Rudolfine world fortunately did not come through this Habsburg equivalent of Bluebeard's castle but through the more sober experience of that seminar with James Allen Vann. For one of our sessions Vann assigned R. J. W. Evans's classic, Rudolf II and His World (Oxford, 1973). This was not an easy read for an undergraduate, but it may have been the very complexity of Rudolf's universe, which Evans describes in such detail, that so beguiled me. Evans constructed a Renaissance unlike anything I had ever encountered. Instead of Leonardo and Raphael and the pleasing balance and harmony of their compositions, I discovered a group of Dutch and Italian artists who distorted proportion and employed strange combinations of color that left me uneasy. And while Rudolf engaged astronomers such as Tycho Brahe and Johannes Kepler to observe and carefully 
measure the heavens, he also set up laboratories for his alchemical experiments and other activities I scarcely understood but knew according to my textbooks were not appropriate behavior for a proper Renaissance prince. This was a Renaissance that also challenged my geographic imagination, for Rudolf s reach seemed immense. From Scandinavia to southern Italy, from England to distant lands of the East, Rudolf sat at the center of a vast cultural web that extended well beyond the terrain of any Renaissance I had studied.

This was also my first real introduction to intellectual history and in many respects my gateway to the professional study of the past. Over time, I came to understand and contextualize Professor Evans's methodological approach to Rudolf and Renaissance Prague. I learned the nature of prosopography, the careful tracing of links between those active at the imperial court. His index alone listed more than five hundred individuals who had some connection with the emperor. At the same time, there were others working in this field, such as Nicolette Mout, who in similar fashion sketched out meticulously those networks that were developing between the Low Countries and Bohemia. ${ }^{1}$ Rudolf II and His World also reflected the influence of Frances Yates with its pan-European focus and interdisciplinary orientation characteristic of the Warburg Institute. Evans took the notion of mannerism from art history and applied it more generally to the intellectual atmosphere of Rudolfine Prague with great effect. Though he expanded his field of study with The Making of the Habsburg Monarchy in 1979, his methodological approach remained similar. It is difficult to underestimate the impact of these two works as they shaped the study of the Habsburg world in fundamental ways on both sides of the Atlantic. Interest in the region grew as other scholars such as Thomas DaCosta Kaufmann highlighted Bohemia's remarkable cultural efflorescence in the visual arts. ${ }^{2}$ Political changes in the 1980s also contributed. The eventual collapse of the Eastern Bloc, easier access to archives and libraries of Czechoslovakia, and a growing desire to reintegrate this region into a broader understanding of Renaissance Europe made Prague an exciting new academic destination.

Though that initial boom has passed and the novelty has faded, Prague's international connections continue to fascinate. In those early days after the wall had fallen, Rudolf retained a prominent place in those first scholarly endeavors that brought researchers together from East and West. ${ }^{3}$ Times have changed, and though the emperor remains important, the field has moved well beyond his castle. Our AHY forum reflects on the current state of research with contributions from a gifted cohort of younger scholars. These essays illustrate not only new emerging interests in Rudolfine Prague and beyond but also reflect more generally critical shifts that have occurred with the study of the Renaissance. Our forum considers at least three major shifts that have taken place. The first and perhaps most dominant theme is the move toward the global, as Europeanists now regularly peer beyond the continent to examine links with the broader world that were developing in this period. The second is a growing interest in material culture. Recognizing the importance of an emerging consumer culture, scholars have devoted more attention to physical goods and objects. Finally, in what is in some respects the continuation of an older dynamic, there has been a sustained and expanding interest with groups that have long stood on society's margins.

Geographically, our forum in fact begins in Afghanistan with Suzanna Ivanič's discussion of a beautiful lapis lazuli rosary created by the celebrated workshop of Ottavio Miseroni with stone from the Badakhshan province. While Ivanič introduces us to a variety of religious objects with a global provenance, Erika Honisch reacquaints us with familiar figures from the imperial court. Honisch as a musicologist reorients our perspective by once more stressing the broad geographic connections that developed in late Renaissance Prague. We encounter Johannes Kepler not in the traditional astronomical context but as a type of cultural critic intrigued but also disturbed by the chanting of a Turkish priest visiting Prague. She also considers the Protestant adventurer Kryštof Harant of Polžice, a key member of the 1618 Bohemian revolt, who when traveling to Jerusalem years earlier examined his

\footnotetext{
${ }^{1}$ M. E. H. N. Mout, Bohemen en de Nederlanden in de zestiende eeuw (Leiden, 1975).

${ }^{2}$ Thomas DaCosta Kaufmann, The School of Prague (Chicago, 1988).

${ }^{3}$ See for example Jaroslava Hausenblasová and Michal Šroněk, Urbs Aurea: Praha císaře Rudolfa II (Prague, 1997); Lubomír Konečný, Beket Bukovinská, and Ivan Muchka, eds., Rudolf II, Prague and the World (Prague, 1998).
} 
own musical compositions in the light of the native traditions of the eastern city. Careful readers of Evans will be quick to point out that these types of themes were not entirely absent in Rudolf II and His World. Among its illustrations is a beautiful drinking vessel created from a "Seychelle-nut" that had made its way to the Habsburg emperor from the northwest coast of Java. Evans also featured the Persian embassy of Shah Abbas, who proposed an alliance designed to crush the Ottomans with a pincer movement from east and west. ${ }^{4}$ The current emphasis, though, is decidedly different. For Suzanna Ivanič, the global is as much methodology as it is geography. Her real quarry is Catholicism and understanding it as a global religion. The Catholicism of seventeenth-century Central Europe was no static phenomenon, and she is keen through her study of its material culture to trace and analyze those various strands that came together from across the continent and beyond to create the baroque religion that flourished in the generation after White Mountain.

Apart from the emphasis on the global, our essays in this forum also reflect a heightened interest in material culture that is representative of the field as a whole. Anna Parker begins her fascinating examination of Jewish Prague with a discussion of a lost clasp. She uses this brooch as an entry point to explore the neglected world of Jewish pawning in Central Europe, where goods and objects circulated along well-established routes to support a hidden economy. Ivaničss lapis lazuli rosary is but one of many objects that she identified from more than 150 inventories of Prague burghers to help recreate the materiality of Catholic piety. Art historian Ivana Horacek introduces us to a very different set of objects. Her subjects are the scientific instruments of the Danish astronomer Tycho Brahe as represented in his Astronomiae instauratae Mechanica (1598), a text dedicated to Rudolf II in an effort to win imperial patronage. Horacek, whose focus is on the heavens, suggests that for Brahe these illustrations were an essential element of a rhetorical strategy that invited the reader to participate alongside the astronomer. Brahe designed the illuminated illustrations of his instruments to bring his readers alongside himself and follow those practices of repeated observation and inspection central to his profession.

A final aspect to consider with our forum is a type of decentering phenomenon that occurs on multiple levels in our four articles. Evans's pioneering work opened up a universe that was almost unknown in Anglophone scholarship. But this was a world of elites and high culture with Rudolf at its center. Though some of the actors remain the same, such as Brahe, there are others in our collection who represent decidedly different aspects of life in late sixteenth- and seventeenth-century Prague, such as Honisch's visiting Turk. Most striking in this regard is the essay of Anna Parker. While Evans drew our attention to Jewish elites such as the Maharal, the financier Mordecai Meisel, or the learned David Gans who once worked alongside Kepler and Brahe, Parker introduces us to Ester, a local Jewish pawnbroker who is the focal point of the complicated story of the lost brooch. A Christian noblewoman had pawned her expensive clasp with Ester. Its disappearance not surprisingly caused a great scandal. Through a close study of court records, Parker carefully sifts through the details and recreates this fascinating story that sheds light on neglected social and economic dynamics of Prague's ghetto. That this pawnbroker was also a woman opens up a whole series of possibilities to the study of gender and its impact on social and business relations in this community.

Ester's story also decenters geographically. As we follow the trail of the missing clasp, we discover a regional trade grid in which Prague was merely one node of a larger network. By exploring those links between the Bohemian capital and cities such as Poznan, Cracow, and Lublin, Parker shows us the exciting possibilities of comparative work between the Habsburg lands and the Polish-Lithuanian Commonwealth, a scholarly border that today often seems as rigid as the political one of the Cold War. Suzanna Ivanič in yet another way recreates a Prague very different from the one of Robert Evans. The inventories she examines represent not the court but the city, the possessions of merchants, apothecaries, and other townspeople. She also pushes traditional chronological boundaries by moving deep into the seventeenth century, into a period popularly known as one of decline and stagnation. Though Prague suffered significantly from the war and lost the imperial court to Vienna in 1612,

${ }^{4}$ R. J. W. Evans, Rudolf II and His World, 2nd ed. (Oxford, 1997), 77-78. 
its economy, as Ivanič emphasizes, was remarkably resilient. The city renewed and expanded those global trade connections as appetites for the foreign and exotic began to grow once more.

These four articles, then, take us in very new and sometimes surprising directions, but as we have examined change, how the field has evolved since the pioneering scholarship of Evans and Kaufmann, it may be appropriate to conclude by considering what has remained the same. From early days, scholarship on Rudolfine Prague was interdisciplinary. This remains a hallmark of the field, and our forum continues that tradition as we explore music, art, and history with forays into religion and history of science. Those many years ago in that senior seminar, my encounter with Rudolf and Renaissance Prague fired my own imagination of what history could be. Now a younger generation of scholars pushes us forward. As their essays clearly demonstrate, the field of inquiry has grown wider and the possibilities ever broader.

Cite this article: Louthan H (2021). Global Prague: Renaissance and Reformation Crossroads. Austrian History Yearbook 52, 13-16. https://doi.org/10.1017/S0067237821000084 